\title{
Water for Food, Livelihoods and Nature: Simulations for Policy Dialogue in South Africa
}

\author{
A. Kamara and H. Sally \\ International Water Management Institute (IWMI), \\ 141 Cresswell Street, Private Bag X813, Silverton 0127, Pretoria, South Africa. \\ Tel: 2712845 9100; Fax: 27128459110 \\ Emails: ab.kamara@cgiar.org or h.sally@cgiar.org
}

\begin{abstract}
IWMI's research activities on the linkages between water and food security have led to the development of a policy dialogue model - PODIUM - which is a cereal-based simulation model that addresses questions related to water and food security in a global, national and river basin context. This paper presents results of the application of the model to South Africa. This entails, firstly, an assessment of the current macroeconomic trends, food requirements and production potential. These assessments are then used to generate various scenarios on meeting national food production targets, taking into account the country's water resources endowment and the management thereof to meet those requirements. The implications of various policy options for achieving national level food security are discussed. One important point that emerges is the need for adequate and reliable data pertaining to the main drivers of the model: demography, nutritional requirements, cereal imports and exports, performance of the agriculture sector, and climate and hydrological regimes, in order to derive simulations and scenarios that are useful and meaningful for policy formulation.
\end{abstract}

Keywords: water availability, food security, South Africa

\section{BACKGROUND}

In Africa, particularly sub-Saharan Africa, high population growth and inadequate agricultural production may combine with increasing water scarcity to pose serious constraints to future economic development (Webb and Iskandarani, 1998). While the impact of rapid population growth on food security has received a considerable attention over the past decades (Pinstrup-Anderson, 1995), household water security vis-à-vis population growth has only recently acquired a high profile on the development agenda (Webb and Iskandarani, 1998). Since 1970, global water demand has risen at an estimated rate of 2.4 percent per annum, with much higher trends in developing countries due to increasing urbanization and water-intensive agricultural activities (Clarke, 1993). Developing countries are home to the overwhelming proportion of the world's 1.2 billion people without access to clean water, a figure that is expected to significantly increase in the next decades (WHO, 1998). Recent studies have made headway in establishing a link between water scarcity and food insecurity, making the task of ensuring water security for poor households equally as important as ensuring food security (Rosegrant, 1997; Seckler et al., 1998).

Though global food projections indicate growths in food production that may lead to a downward trend in world food prices (Rosegrant and Perez, 1995), food insecurity in Sub-Saharan Africa is expected to prevail or even worsen (FAO, 1995). The reasons for this are numerous but largely relate to low physical productivity in the agricultural sector (irrigated and non-irrigated), with irrigated yields assessed to be lower than many other regions of the world (Rosegrant and Perez, 
1995) ${ }^{1}$. It is clear that there is an acute need to increase food production on the continent by stimulating domestic production, through increasing the intensification and scaling up of smallscale technologies that are sustainable, suitable to local conditions and reduce risks of smallholder production (Merrey et al., 2002).

In their assessment of global water scarcity and food security, Seckler et al. (1998) projected that some countries in sub-Saharan Africa would become physically water scarce in 2025, including South Africa ${ }^{2}$. The other countries were categorized under different forms of economic water scarcity, requiring the development of more than twice the amount of water they currently use to meet reasonable future demands ${ }^{3}$. Faced with the prospect of future physical water scarcity, South Africa has embarked on far-reaching reforms and restructuring of its water sector to serve as a stimulus to redressing inequity, alleviating poverty and promoting economic development. This has also given rise to the need for developing and applying appropriate research and planning tools in support of policy and decision-making.

This paper presents the first results of an application of the policy dialogue model, PODIUM, to South Africa. The broad aim of this exercise is to assess the water situation in the country as it relates to food security at various levels, giving options of how national level challenges of food security could be met through a combination of domestic production (under various scenarios of water constraints) and trade options. National level food requirement are appraised from relevant macro economic variables such as present population, growth rates, daily dietary intake and proportion of cereals and animal products in diet. Options such as domestic production via irrigated or rainfed agriculture are examined using various parameters - water requirements, yields (irrigated and rainfed), potential irrigable land, etc. These are then weighed against trade alternatives as permitted by import and export options of basic foods. Each domestic production option is then converted into water requirements to generate policy implications vis-à-vis the available water resources.

\section{WATER MANAGEMENT CHALLENGES IN SOUTH AFRICA}

About two-thirds of South Africa is arid or semi-arid. Rivers in the country are few and relatively small when compared to major rivers on the African continent ${ }^{4}$, and are largely shared internationally - about 65 percent of the land area of South Africa falls in internationally shared river basins (Hirji et al., 2002: 29). Annual rainfall across the country averages around $450 \mathrm{~mm}$ per annum, which is barely half of the global average (RSA, 2002). The magnitude and distribution of rainfall subject large parts of the country to extremes of periodic droughts and floods, emphasizing the crucial need for efficient management of water resources as a national priority. This is reflected in the comprehensive water policy, the National Water Act (NWA) ${ }^{5}$.

\footnotetext{
${ }^{1}$ As presented in Rosegrant and Perez (1995), FAO data bases indicate that crop yields in both rainfed and irrigated agriculture in Sub-Saharan, for most crops, lag far behind that of other regions (Rosegrant and Perez (1995: 99).

2 These estimates were based on a threshold value of $40 \%$ of the potentially untilizable water resources for ecological reserve. However, national estimates, using a threshold value of about $20 \%$ for ecological reserve indicate that South Africa (with improved water management) may not necessarily be physically water scarce by the year 2025 (RSA, 2002 ).

${ }^{3}$ Physical water scarcity refers to a situation of having developed most of the available water resources of a country, leaving only demand management and reallocation options, and improving the efficiency of storage, diversion and delivery structures. On the other hand, economic scarcity draws attention to the lack of human and financial resources, as well as technical capacity, to develop more water resources to meet growing needs.

${ }^{4}$ The four main rivers are the Orange, Limpopo, Inkomati and Pongola Rivers. While these rivers remain relatively small (e.g. the Orange River, for instance, carries only about $10 \%$ of the flow of the Zambezi or $1 \%$ of the Congo River), they are all shared with neighboring countries - Orange: shared with Lesotho and Namibia; Limpopo: shared with Botswana , Mozambique and Zimbabwe; Inkomati and Pongola: shared with Mozambique and Swaziland (RSA, 2002).

5 The ratification of the National Water Act (NWA) in 1998 converted the longstanding riparian water rights in South Africa into a new management system, in which the state becomes a custodian to all water resources in the country. Existing individual and group rights to water for productive and consumptive uses were preliminarily recognized, subject to registration, subsequent review and licensing by competent authorities (the Catchment Management Agencies, CMAs) in the country's 19 water management areas. To date however, about 90 percent of the CMAs are yet to be established.
} 
The NWA pledges that the process of water management should create a new window of opportunities for previously disadvantaged individuals to improve their socio-economic situation while contributing to national economic development. It sets out ways in which this could be achieved through a legally binding framework within which water resources in the country will be protected, used, developed, conserved, managed and controlled for the benefit of all (RSA, 1998). A National Water Resource Strategy (NWRS) that seeks to define the framework and priorities that should guide the implementation of the Act is being developed. Of these priorities, the provision of relevant information to all tiers of water users and the general public, and the identification of ways in which the available water resources could support social and economic development are emphasized (RSA, 2002). Seeking to strike a balance between efficient water utilization allocation to high value uses in the context of growing water scarcity - and striving to achieve equitable access for all, including smallholder agricultural producers and domestic users is a formidable challenge. Hence the National Water Act specifically calls for pro-poor strategies that emphasize the principle of 'some for all' rather than 'all for some'.

The entire country is divided into 19 water management areas. According to the NWA, the ecological reserve for each water management area is given the highest priority and is immediately followed by basic water needs for human consumption ${ }^{6}$. After the reserve and basic human needs, the next priority in each Water Management Area is water for basic productive uses, the so called Schedule 1, which sets aside certain water uses that are permissible under any circumstance. This includes water for reasonable domestic use, including smallholder livestock and small-scale gardening not for commercial purposes (Schreiner and van Koppen, 2001) ${ }^{7}$. After these basic needs and Schedule 1, compulsory licensing may then be introduced where and when needed, which will cancel and replace all existing licenses on the basis of a new allocation schedule. Even though the Department of Water Affairs and Forestry is chiefly responsible for implementation, strong vertical and horizontal cooperative governance between government departments is envisaged for crystallizing the process that will eventually be taken over by the Catchment Management Agencies (CMAs).

The realization of the challenge of ensuring equitable access to water by all stakeholders, particularly the poor, in a situation of growing water scarcity, will largely depend on the ardent efforts to increase the productivity of agricultural water use by smallholders, a move that is already recognized nationwide (RSA, 2000). Furthermore, effectively addressing questions related to water reallocation will not only rely on conventional productivity indicators such as crop per drop or monetary value per drop (which immediately favors sectors such as mines), but also on equity indicators such as jobs per drop or number of people or livelihoods dependent on a given quantity of water. If successfully implemented, this pro-poor orientation will perhaps be the greatest achievement of this new, water-focused developmental approach.

\section{THE POLICY DIALOGUE MODEL, PODIUM}

The policy dialogue model, Podium, is a cereal-based decision support tool for generating policy options related to national level food security and water availability. The model provides an analytical framework to structure discussion about future water and food demand (Seckler, et al. 1998). Based on assumptions about macroeconomic variables, the model is used to determine water demand in 2025 to meet food requirements resulting from population growth and changing diets. It does not provide definitive predictions but rather analyses "what if" questions that relate to population growth, per capita calorie intake, changing proportion of grain-meat ratio in dietary

\footnotetext{
6 The current policy has set these basic consumption needs at 25 liters per person per day (about half of the requirements of the Dublin Principles of 1992), though in the year 2000, there was a government decision to provide the first 6,000 liters per household free (Schreiner and van Koppen, 2001).

7 As noted by Schreiner and van Koppen (2001), it is becoming increasingly realized that farming and gardening by small farmers is often (sometimes partially) market oriented. Thus, it is debatable whether the extent of Schedule 1 should be limited to land area (e.g. less than 2 hectares) or to a certain income, say slightly above the poverty line.
} 
requirements, domestic production from rainfed and irrigated agriculture, import options and the available potentially utilizable water resources.

\section{Model Structure}

The basic structure of the model consists of three main components, which include the cereal demand drivers, the cereal production drivers, and water balance indicators. The cereal demand drivers relate to total population and projected growth rates, food and feed requirements for humans and livestock respectively, and import/export balances. The cereal production drivers relate to irrigated and non-irrigated areas, crop yields and cropping intensities. The cereal balance and proportions of cereals grown through irrigated and rainfed agriculture will then determine the water requirement for irrigation. The water diversion for irrigation, domestic and industrial uses altogether constitute the water requirements of the country that must be met from primary diversions (diversion for the first time) as well as from recycling of water that has been diverted at least once. The model structure and key variables in the analysis are highlighted in Figure 1.

\section{Figure1: National-level food and water requirements}

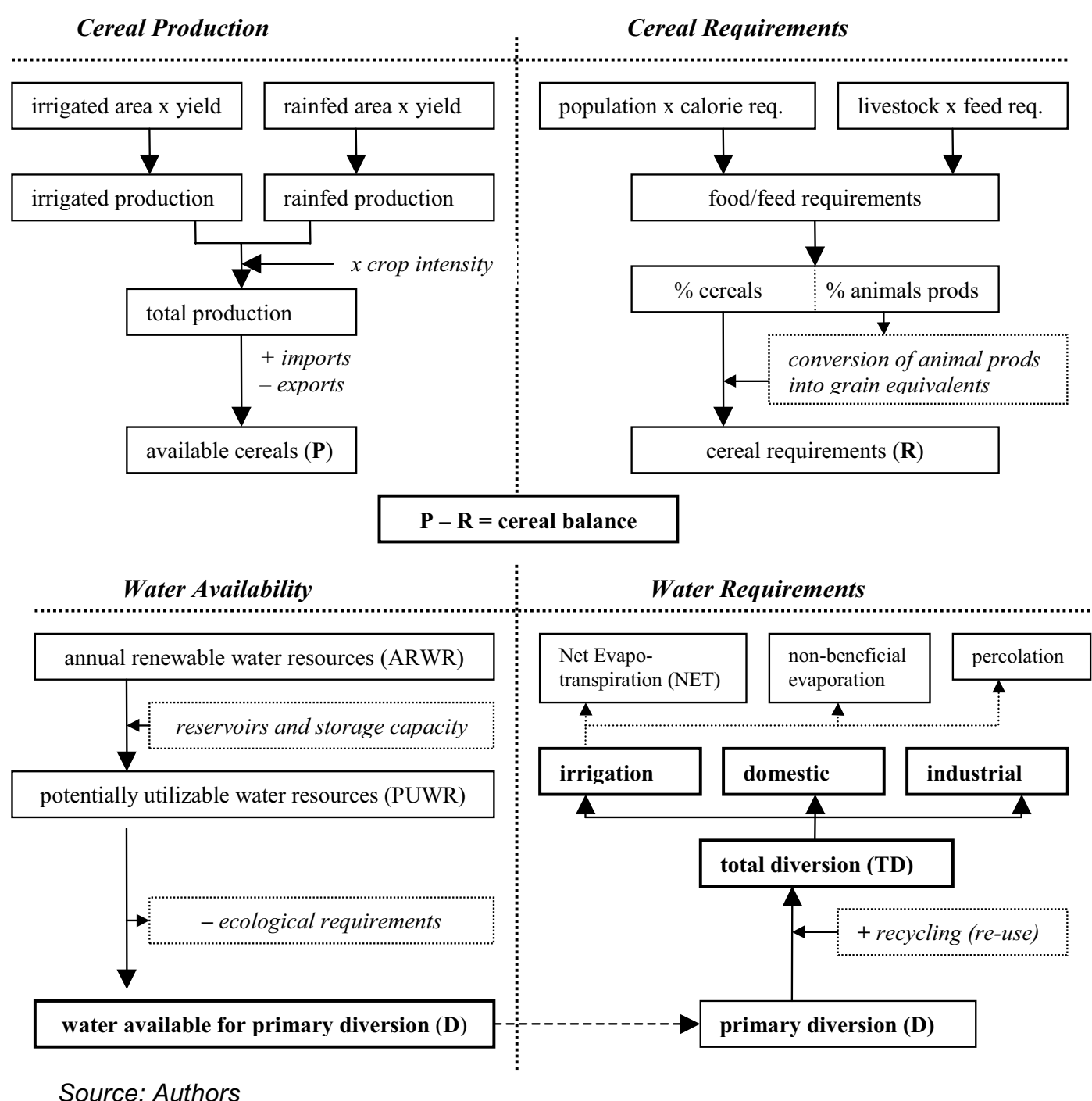




\section{Water Resources}

The annual renewable water resources (ARWR) is the sum of all runoff generated within a country plus any inflows into the country less outflows committed to neighboring countries ${ }^{8}$. But only a certain proportion of the ARWR will be actually available for utilization in the country, depending on the practical and economic storage facilities, including reservoirs and aquifers. This is referred to as the potentially utilizable water resource (PUWR). In addition, the South African legislation requires that a certain proportion of its water resources be committed to the environment (wetlands, maintenance of aquatic biodiversity, etc.) ${ }^{9}$. It is the net amount remaining after meeting the ecological reserve that is available for diversion for agricultural, domestic and industrial uses.

With a current population of about 44 million and annual renewable fresh water resources of about 50 cubic kilometers (RSA, 2002), per capita water availability in South Africa is projected to be among the lowest in the SADC ${ }^{10}$ region by 2025 (Hirji et al., 2002). Rapid population growth, urbanization and increasing water demand pose a major challenge of attaining water security in the country. While population is growing at an annual rate of about 2.4 percent (IWRM, 2002), per capita water availability is declining, at a recorded rate of about 10 percent in five years (1995 2000) and a projected decline of about 21 percent in the next three decades of $1995-2025$ (Figure 2). The country's heavy reliance on surface water (for domestic, industrial and agricultural uses), which is highly dependent on fairly unreliable rainfall, has important implications for efficient water management in the country. Groundwater utilization is not very extensive and is limited largely to rural areas, with large aquifers occurring only in few areas (Basson, 1987).

\section{Figure 2: Population growth and per capita water availability in South Africa}

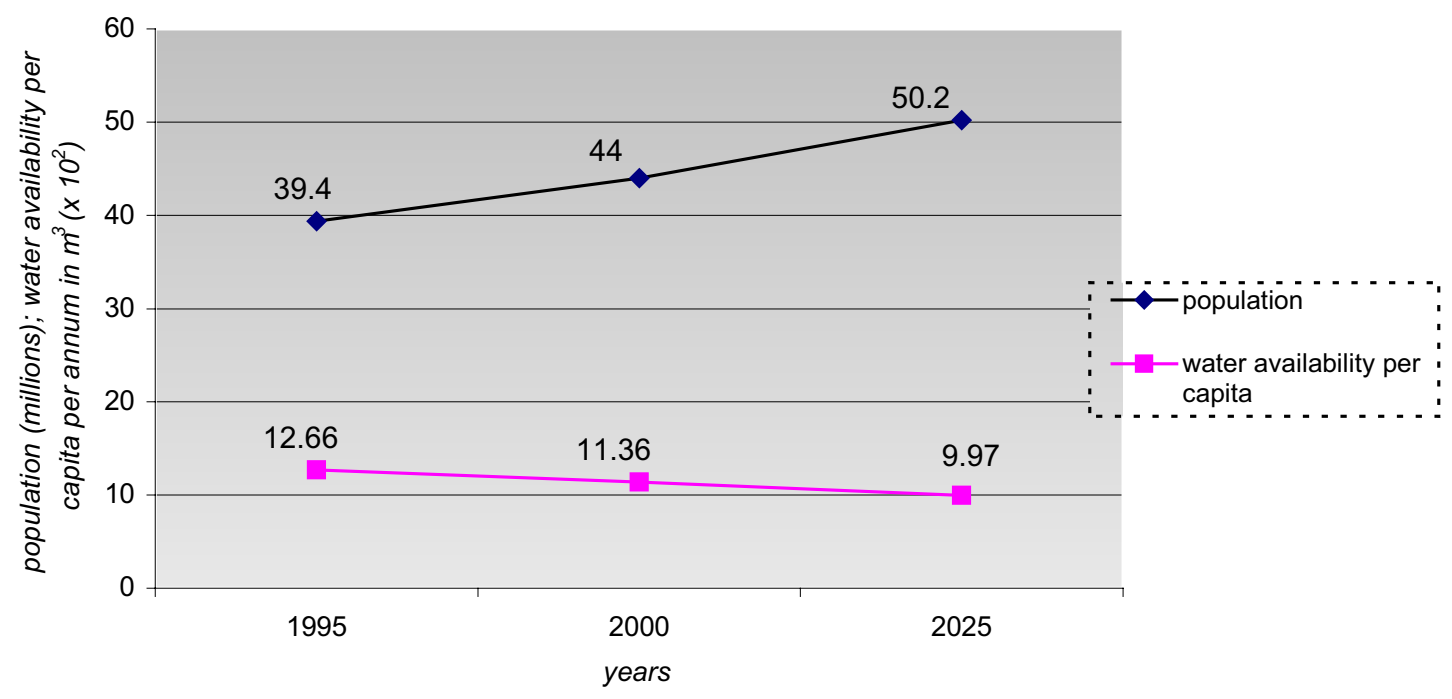

Source: Computed from SADC technical data (Hirji et al., 2002)

From the average annual mean runoff generated in the country and the percentage of reliable yields, it is estimated that even with a tentative threshold value of about 20 percent for the environmental reserve, many of the water management areas would exhibit water deficit (RSA,

\footnotetext{
${ }^{8}$ Runoff is estimated precipitation minus direct evaporation from rainfall by land covering including natural vegetation, crops, and bare soils. Average precipitation is generally used in determining ARWR, with specified probability levels (IWMI, 1999), where ARWR excludes discharge from ground water in excess of recharge from precipitation.

The figure for environmental requirement in South Africa is still under discussion but is highlighted in the new water resources strategy to be an average value of about $20 \%$ of the natural mean annual runoff, which is used as for the Podium simulations in this study.

${ }^{10}$ Southern Africa Development Community
} 
$2002)^{11}$. While the potential for inter-basin transfers remains limited, it is prudent to expect that increase in water demand (growth in domestic, urban, industrial requirements, etc.) may lead to water-stress even in water management areas that may currently appear to have sufficient water. Overall, irrigation accounts for about 60 percent of the total water requirement of the country, which may not necessarily be justified by its contribution to the GDP (only about $4.5 \%$ ), but by the relatively large number of people, particularly the poor and vulnerable groups, whose livelihoods depend on it.

\section{Population Growth and Food Requirements}

Depending on the source, population projections for 2025 range between 50 million to over 60 million (UNECA, 2001; ILO, 2002), mainly on account of the uncertainty attached to impacts of HIVIAIDS and the unreliability of census data that form the basis for such projections. Whichever of these figure is realized, it is obvious that the huge population increase in the next decades will be accompanied by a growing food demand, which will require strategies and options for augmenting domestic production or increasing imports, based on comparative economic advantage.

About 90 percent of South Africa's food consumption is met by domestic production. But population growth and increasing food demand creates additional pressure on the country's arable land and water resources given its high dependency on irrigation (Jooste and van Zyl, 1999; Hirji et al., 2002). As a middle-income country, the food situation in South Africa is largely characterized by apparent national level food self-sufficiency, though millions of households are threatened by household-level food insecurity, especially those without access to land and other productive resources (RSA, 1997). This clearly points to the huge disparity between national level food availability and household level food security in the country ${ }^{12}$. With the second most skewed land distribution in the world, the proportion of South Africans vulnerable to food insecurity due to lack of access to productive resources is very high, estimated at about fourteen million (RSA, 1997).

Since the concerted efforts by SADC countries to remove the restrictive measures in agricultural markets in the 1980s, countries in the region have been open to the 'opportunity' of international competition, especially with the increasing globalization and liberalization of agricultural markets worldwide. International competition in agricultural markets requires efficient use of resources, and exploitation of comparative advantage (where it exists) to enhance the competitiveness of domestic producers. Therefore strategies for meeting the projected increase in food demand in South Africa in the next decades have to be based on a critical assessment of the country's productive natural resources, mainly land and water resources (abundance, availability, opportunity cost for usage in home production, etc.), and of the feasibility and comparative advantage of home production versus import options.

Even though South Africa's import records show a fairly low and stable figure of less than 10 percent on the average over the last three decades for cereals, spontaneous shocks such as the droughts in 1992 - 1993 (over 50\% of cereal import) and in 1995 - 1996 (over $20 \%$ cereal import) cannot be ruled out (FAO, 1998; Jooste and van Zyl, 1999). This has implications for assessing water management options and stimulating home production where opportunities exist, especially for the rural masses, who often, are net consumers of locally-produced agricultural products.

\footnotetext{
${ }^{11}$ As stated in the new national Water Resources Strategy, deficit in most cases, may not necessarily imply that demand exceeds supply, but that the needs for ecological requirements may not be fully met while also satisfying various uses and users (RSA, 2002).

${ }^{12}$ In this context therefore, there is a clear difference between food availability as determined by domestic production, importation and efficiency of distribution, and food accessibility which is primarily determined by the ability of households to obtain sufficient food for all members at all times either through own production or through exchange, usually via market mechanisms.
} 


\section{Water Scarcity Indicators in PODIUM}

One of the key indicators in the model that determines the national level water situation is the degree of development, which refers to the primary diversions expressed as a percentage of the potentially utilizable water resources. The degree of development is what determines whether current water resources development strategy is sustainable or not. This assessment is expressed in terms of physical and economic water scarcity. According to the model, a country is physically water scarce if the degree of water resources development is greater than the proportion of the potentially utilizable water resources available for diversion after the environmental reserve has been met. In the model, the threshold value for degree of development is 60 percent for most countries, but may vary from country to country. In the current estimations for South Africa, the degree of development is assigned a value of 80 percent, reflecting the proposed 20 percent environmental reserve suggested in the national water resources strategy.

The second important indicator is the growth in total diversions (TD), which indicates whether or not a country is economically water scarce. A country is considered economically water scarcity if it will be necessary to increase water supplies by development of additional storage, conveyance and regulation systems equivalent to more than 25 percent of the 1995 levels (i.e. $T_{1} D_{1995} / T^{2025}>$ 1.25) (Seckler et al, 1998). Economic scarcity therefore reflects a country's inability to make the necessary investments in water development and associated infrastructure.

\section{SIMULATIONS, RESULTS AND DISCUSSION}

\section{Data Sources, Simulations and Scenarios}

The default data in the model is based on the year 1995 as a reference year. The data is secondary, obtained largely from the databases of FAO, IWMI, World Resources Institute, United States Department of Agriculture, the World Bank, etc. These data were verified against available local data at the South African institutions such as the National Department of Agriculture, the Department of Water Affairs and Forestry, the Agricultural Research Council, the Central Bureau of Statistics, etc. and, as far as possible, the local-level data were entered as inputs. The first section of the data covers basic demographic and nutrition information for 1995 (the base year) and estimates for 2025 predicted from other models. Cereal and livestock production and consumption as well as import/export balances and predicted growth rates are entered into the model. This includes both irrigated and non-irrigated areas and yields, irrigation intensity and efficiency, as well as growth in irrigated area. Basic hydrological and climatic data on precipitation, annual renewable water resources, potentially utilizable water resources, current and future diversions, recycling, ground water availability, application efficiency, recharge of aquifers, and evapotranspiration data are also entered as inputs, which then form the basis for the scenario computations.

On set of factors examined in the scenario testing were population, options of meeting food security through irrigated area increase and increasing the efficiency of irrigation water use or through yield improvements. A second set that was examined was the impact of increasing the daily water allocation per capita for basic human needs, so as to assess the effects on the degree of development which determines whether current development strategies are sustainable or not.

\section{Population, Food Security and Water Resource Development}

According to UN world population database, there are four variants of population growth prediction in South Africa in the next decades: the low, medium, high and constant variants (UN, 2001). Each of these variants project different rates of fertility, birth and mortality, with some assumptions on the long-term impacts of HIVIAIDS. These variants were tested vis-à-vis food requirements and water resources development, taking the current and predicted levels of daily calorie in-take into account, as well as import/export requirements. With a current population of about 44 million people that is projected to grow to over 60 million in 2025, the population scenarios were run keeping the current levels of cereal import and export, with the assumption that over 90 percent of food grain 
requirements are met from domestic production as is currently the case. Current irrigated yields are kept constant but the net irrigated area (1.27 million ha) is allowed to grow at a rate of about 1.16 percent per year. The results of the population scenarios are summarized in Table 1.

Table 1: Population scenarios: water and food demands (2025)

\begin{tabular}{|c|c|c|c|c|}
\hline \multicolumn{2}{|c|}{ Population 2025 (million) $^{d}$} & \multicolumn{3}{|c|}{ Water development and food security indicators } \\
\hline variant & predicted & $\operatorname{DOD}(\%)^{\mathrm{a}}$ & Growth $(\%)^{\mathrm{C}}$ & food security ${ }^{b}$ \\
\hline Low & 39.96 & 67 & 28 & 2.0 \\
\hline Medium & 43.77 & 68 & 29 & 0.73 \\
\hline High & 47.52 & 69 & 31 & -0.51 \\
\hline Constant & 49.21 & 69 & 32 & -1.08 \\
\hline UN-ECA & 66.90 & 72 & 40 & -6.96 \\
\hline \multicolumn{5}{|c|}{ Agricultural water productivity (crop per drop): $1.18 \mathrm{~kg} / \mathrm{m}^{3} \mathrm{ET}$} \\
\hline \multicolumn{5}{|c|}{$\begin{array}{l}\text { a Degree of Development (\% of potentially utilizable water resources) } \\
{ }^{\mathrm{b}} \text { National level food security: surplus }(+) \text { and deficit }(-) \text { in Million Tons } \\
{ }^{c} \text { Growth in total water diversions to agriculture, domestic and industrial uses (in \%) } \\
\text { d Projections: UN-Population Division and the ECA (Economic Commission for Africa) } \\
\text { Source: Podium, Model Estimations } 2002\end{array}$} \\
\hline
\end{tabular}

These results indicate that at current levels of water resources utilization, irrigation efficiencies, and crop yields, South Africa will experience food deficit if the high population growth predictions eventually obtain - that is, about 48 million and above for 2025. The current degree of development shows that at current trends of water allocation to agriculture and a 20 percent environmental reserve, the country is not likely to be physically water scarce even if the population were to reach 66 million, although a dramatic growth in total diversions is expected, i.e. more primary diversion as well as re-use or recycling - diversion of water that been used at least once. These increases in total diversions may imply a need for huge investments in technology, diversions and delivery structures, as well as in the monitoring of quality standards (and purification) across sectors to facilitate recycling or re-use.

\section{Figure 3: Population growth and water resource development scenarios}

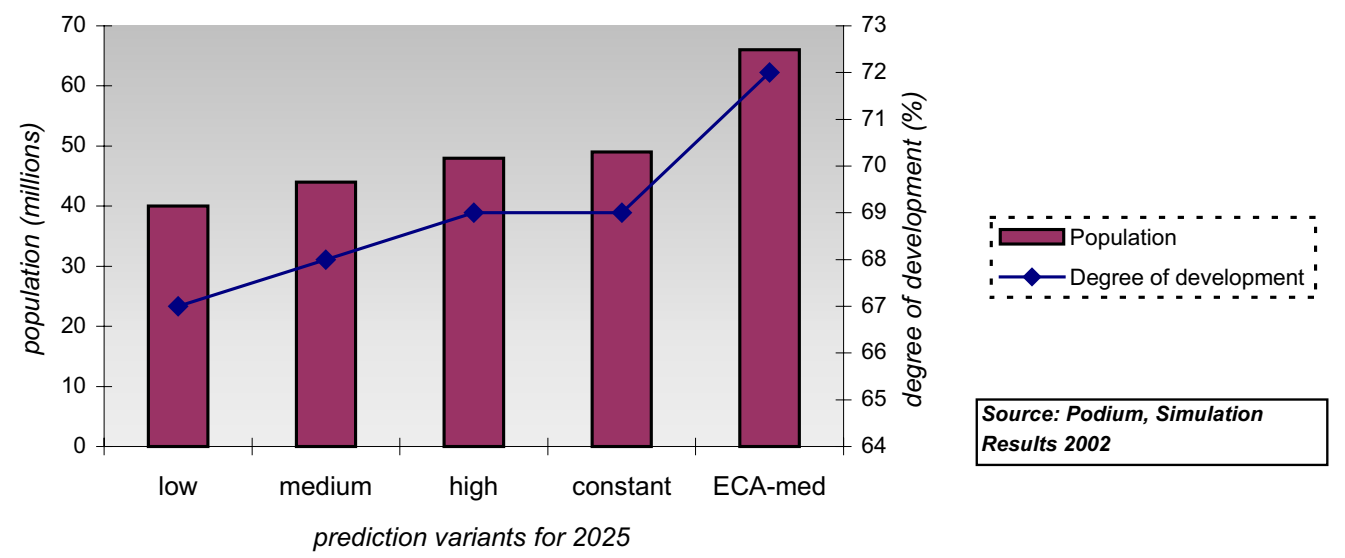

The positive correlation between population increase and degree of development appears to be sustainable until the population reaches about 70 million, when the degree of development surpasses the threshold of 80 percent, signaling physical water scarcity and implying the existence of little or no more options for further water resources development. At this stage, the country will largely rely on reallocating water and improving the efficiency of water use in all sectors. In the 
agricultural sector, the current productivity of water or 'crop per drop' (aggregated for all technologies) is $1.18 \mathrm{kgm}^{-3}$ of ET. This figure will surely vary considerably across different parts of the country, and across irrigation systems using different technologies. If the low growth population variants obtain (e.g. due to the impact of HIVIAIDS and lack of anti-retroviral drugs), then a food surplus is envisaged if current production and productivity parameters continue to prevail. Figure 3 highlights the relationship between population growth and the changing degree of water resources development to meet food requirements.

\section{Irrigated Area Increase and Water Resource Development}

Based on soil conditions, agro-ecological and climatic factors, water availability and sustainability, it is estimated that South Africa has an irrigation potential of about 1.5 million ha, of which only about 1.27 million ha has been developed to date (IWRMS, 2002). Flood and sprinkler systems account for about 88 percent of the total irrigated area of South Africa. Being the most widespread, their efficiency levels were used in running scenarios on irrigated area increase. Separate scenarios were also developed on options for varying the efficiency levels, using different technologies. The simulation results for the scenarios on irrigated area increase are presented in Table 2.

Table 2: Irrigated area increase: water and food situation (2025)

\begin{tabular}{|c|c|c|c|c|c|}
\hline \multicolumn{3}{|c|}{$\begin{array}{l}\text { Increase in net irrigated area } \\
\text { (2025 million ha; current } 1.27)\end{array}$} & \multicolumn{3}{|c|}{$\begin{array}{l}\text { Water resources development } \\
\text { and food security indicators }\end{array}$} \\
\hline annual \% & total \% & actual area & $\mathrm{DOD}(\%)^{\mathrm{a}}$ & growth $(\%)^{\mathrm{c}}$ & food security ${ }^{b}$ \\
\hline 0.32 & 10 & 1.377 & 59 & 13 & -0.23 \\
\hline 0.47 & 15 & 1.461 & 61 & 16 & -0.18 \\
\hline 0.61 & 20 & 1.524 & 63 & 20 & -0.14 \\
\hline 0.75 & 25 & 1.588 & 65 & 23 & -0.10 \\
\hline 0.88 & 30 & 1.651 & 67 & 27 & -0.05 \\
\hline 1.13 & 40 & 1.778 & 71 & 34 & 0.03 \\
\hline \multicolumn{6}{|c|}{ Agricultural water productivity (crop per drop): $1.18 \mathrm{~kg} / \mathrm{m}^{3} \mathrm{ET}$} \\
\hline \multirow{2}{*}{\multicolumn{6}{|c|}{$\begin{array}{l}\text { a Degree of Development (\% of potentially utilizable water resources) } \\
\text { b }{ }^{b} \text { National level food security: surplus }(+) \text { and deficit }(-) \text { in Million Tons }\end{array}$}} \\
\hline & & & & & \\
\hline \multicolumn{6}{|c|}{${ }^{\circ}$ Growth in total water diversions to agriculture, domestic and industrial uses (in \%) } \\
\hline
\end{tabular}

The scenarios indicate that irrigated area development up to about 1.58 million ha seems sustainable, though area expansion by itself will not easily address national level food security. From irrigated area expansion alone (keeping current yield levels and import/export situation the same), national food balance becomes positive only at a 40 percent increase in irrigated area (to about 1.778 million ha), which is quite infeasible both from a theoretical perspective and from the growth in total diversions estimated by the model, which far exceeds the 25 percent threshold beyond which huge investments are needed (and which may not easily be realized). The degree of development also approaches its permissible limit, though water productivity in the irrigation subsector (crop per drop) remains unaffected. The limits to irrigated area expansion draws attention to the need to examine other intensification possibilities and yield enhancing options in both irrigated and rainfed agricultural production, as a means of achieving food security.

The potential for improving the efficiency of agricultural water use through increases in the efficiency of irrigation systems was also examined. The possibility of increasing irrigation efficiency from 55 through 65 percent (flood), to 75 and 80 percent (sprinklers) was examined and the effects on water resources development and growth in total diversion assessed. The results are presented in Figure 4. 
Figure 4: Irrigation efficiency and water resources development

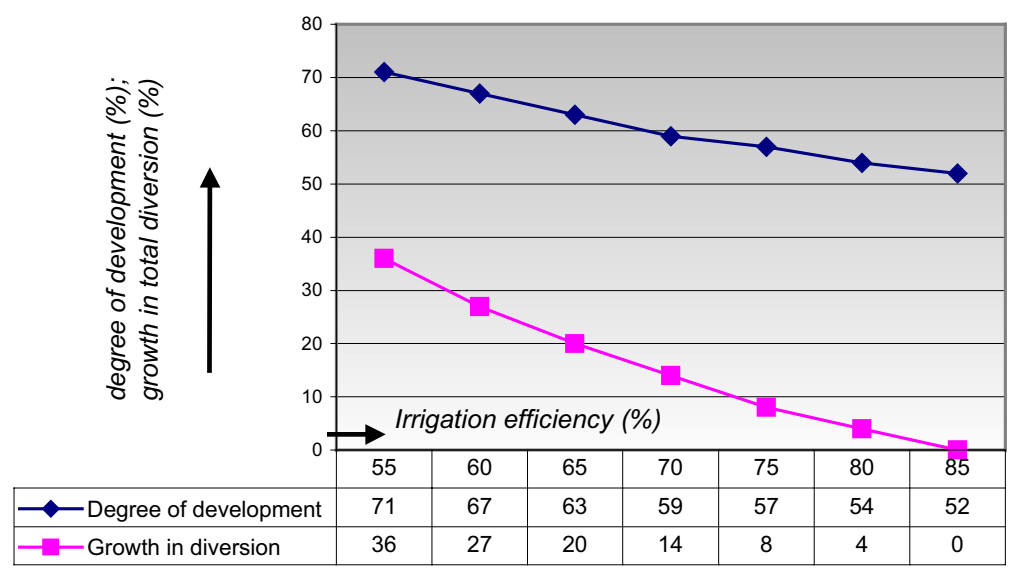

Source: Podium, Simulation Results 2002

The results indicate that a 5 percent improvement in irrigation water use efficiency would reduce total diversions by 10 percent, and the degree of development by 5 percent. The reduction in total diversions continues until about 85 percent efficiency when there will be no more need to increase current diversions. The degree of development at this stage is around 60 percent, which shows that current diversion rates can be quite sustainable with some improvement in irrigation water use.

\section{Daily Domestic Water Use Per Capita}

About 70 percent of the population in South Africa has access to piped domestic water supply (RSA, 1997). Increasing both the number of people with access to basic domestic water as well as increasing per capita daily water consumption is a big challenge in the new National Water Act (RSA, 2002). Accordingly therefore, some scenarios to test the physical and technical (economic) possibilities of achieving these aims were carried out.

Figure 5: Daily domestic water use per capita

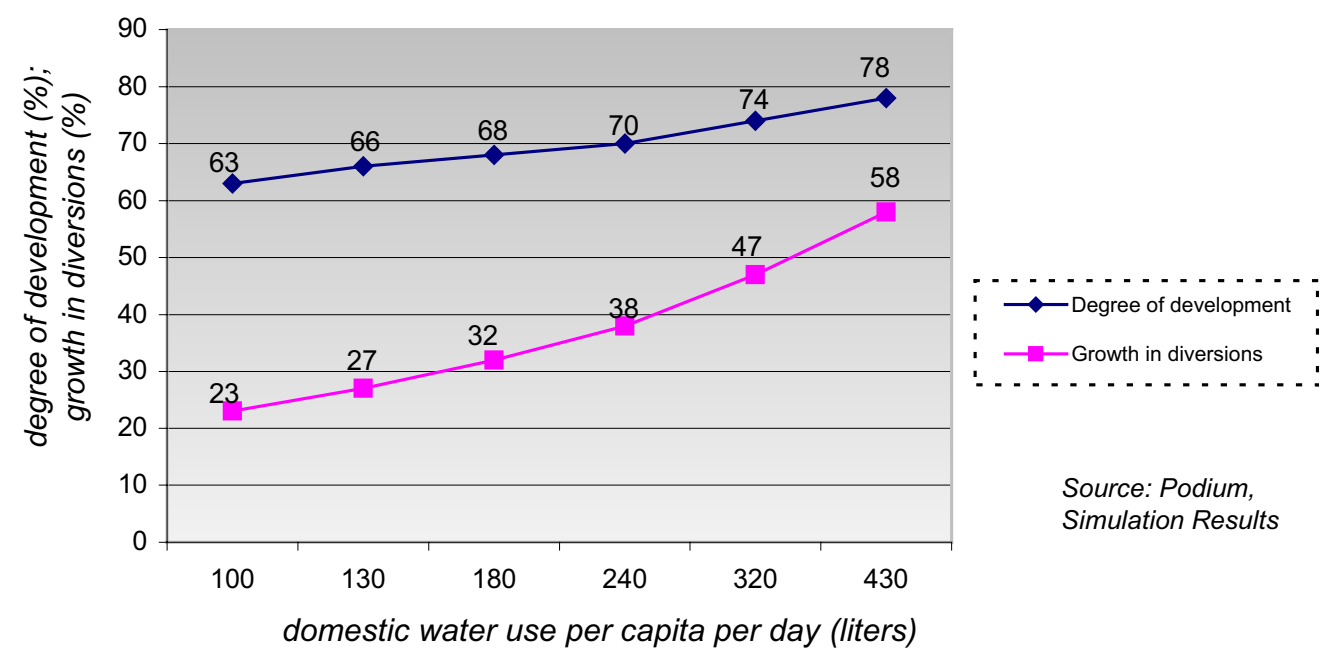

The base scenario projects a target of daily domestic water use of 100 liters per person per day in 2025 , for the entire population. That is, 100 percent of the population would have access to basic domestic water in 2025 . The implications of increasing this daily domestic water requirement per 
capita to higher targets in 2025 were further examined in the context of economic and physical water scarcity. At current rates of diversion and environmental requirements, the scenarios indicate that domestic water consumption per capita can be increased up to about 130 liters per day without economic water scarcity. Beyond this level however, there would be a need for considerable investments in water resources development to meet higher targets of per capita domestic water consumption. At 430 liters per person per day, physical water scarcity sets in with the degree of development reaching the permissible limit of 80 percent. Figure 5 highlights the simulation results of providing $100 \%$ access to basic domestic water and increasing the daily per capita water use.

\section{CONCLUSIONS AND POLICY IMPLICATIONS}

Per capita water availability as depicted by total population vis-à-vis potentially utilizable water resources is decreasing year after year in South Africa, making the task of securing adequate water resources to meet the demands of a growing population ever more challenging with major implications for national water security as well. Podium simulations with different population scenarios point to a food deficit by 2025 if the high population projections come to prevail, unless there are improvements in water resources utilization, irrigation efficiencies and crop productivities, or a change in the import-export ratio, which would have foreign exchange and balance of payments implications. The degree of development with high population scenarios and prevailing trends of water allocation to agriculture, and a 20 percent environmental reserve, shows that the country is not likely to be physically water scarce by 2025 , even though a dramatic growth in total diversions is expected with its associated investment needs. This may indicate that there are still opportunities for water resources development in South Africa without necessarily depleting the resources or compromising the ecological reserve. It also draws attention to the fact that South Africa should not expect to be self sufficient in food especially if the higher population projections obtain, unless efforts to stimulate domestic production by increasing productivity in irrigated agriculture and intensifying rain-fed agriculture.

Scenarios of expansion of irrigated area indicate that an increase in irrigated area, even up to the theoretical irrigation potential, may not by itself make a significant impact on national level food security. National food balance becomes positive only at a total irrigated area of about 1.7 million ha, which is not only out of the theoretical range but is physically infeasible due to the huge increase in total water diversions. The simulation results however indicate that a 5 percent overall improvement in irrigation efficiency would reduce total diversions by 10 percent. This emphasizes that there is a real possibility for modest increases in irrigated area and improvement in efficiency, without necessarily creating a need for huge diversions to the agricultural sector. Therefore both technical and institutional options for efficiency improvements in irrigation schemes are worth examining. Also, at current rates of diversion and environmental requirements, there seems to be an opportunity for sustainably achieving higher targets of household water security, of up to about 400 liters per person per day in 2025. Although this is associated with heavy investment requirements (especially beyond 130 liters per capita per day), it is quite feasible from the perspective of the available water resources.

\section{REFERENCES}

Basson, M. S., 1997. Overview of water resources availability and utilization in South Africa. Department of Water Affairs and Forestry, Pretoria, South Africa.

Clarke, R., 1993. Water: The International Crisis. Cambridge, Ma: MIT Press.

Hirji, R., Johnson, P., Maro, P., and Matiza Chiuta, T. (eds.) 2002. Defining and Mainstreaming Environmental Sustainability in Water resources Management in Southern Africa. SADC, IUCN, SARDC, World Bank: Maseru/Harare/ Washington. 
ILO (International Labor Organization) 2002. HIVIAIDS in the World of Work. Global Program on HIVIAIDS and the World of Work. Geneva. http://www.ilo.org/aids

IWRMS (Integrated Water Resources Management Systems), 2002. Water resources of South Africa. Institute of Geography, FSU Jena. http://www.iwrms.uni-iena.de

Jooste, A. and van Zyl, J. 1999. Regionla Agricultural Trade and Changing Comparative Advantage in South Africa. USAID Technical Report No. 94. Regional trade Agenda Series. U. S. Agency for International Development

Merrey, D., de Lange, M., Gichuki, F., van Koppen, B., Inocencio, A., Kamara, A., Crosby, C., Levite, H., and Sally, H. 2002. Agricultural Water Use and Improving Rural Livelihoods in sub-Saharan Africa: Current Status, Future Directions, and the Role of the International Programme for Technology and Research in Irrigation and Drainage (IPTRID). Keynote Paper: International Congress for Irrigation and Drainage (ICID), Montreal, Canada, 23 July 2002.

Pinstrup-Anderson, P. 1995. A 2020 Vision for Food, Agriculture and the Environment: The Vision, Challenge and Recommended Action. International Food Policy Research Institute, IFPRI. Washington, D.C.

Rosegrant, M. W. 1997. Water resources in the Twenty-First Century: Challenges and Implications for Action. Food, Agriculture and the Environment. Discussion Paper No. 20. International Food Policy Research Institute (IFPRI), Washington, D. C.

Rosegrant, M. W. and Perez, N. D. 1995. Water Resources Development in Africa: A Review and Syntheses of Issues, Potentials and Strategies for the Future. International Food Policy Research Institute (IFPRI), Washington, D.C.

Rosegrant, M., W. and Ringler, C. 1999. Impact on Food Security and Rural Development of Reallocating Water from Agriculture. EPTD Discussion Paper No. 47. Environment and Production Technology Division, International Food Policy Research Institute (IFPRI), Washington, D.C.

RSA (Republic of South Africa) 1997. Food Security Policy for South Africa: A Discussion Document. Agricultural Policy Unit, Department of Agriculture and Land Affairs: http://www.nda.agric.za/docs/Foodsecurity/foodsecurity.htm

RSA (Republic of South Africa) 1998. National Water Act. Government Gazette. Vol. 398. 26 ${ }^{\text {th }}$ August 1998. No. 19182. Cape Town: Office of the President.

RSA (Republic of South Africa) 2002. National Water Resources Strategy: Proposed First Edition: Summary. Department of Water Affairs and Forestry (DWAF), Pretoria.

Schreiner, B. and van Koppen, B. 2001. Catchment Management Agencies for Poverty Eradication in South Africa, International Water Management Institute, Pretoria.

Seckler, D., Amarasinghe, U., Molden, D., de Silva, R. And Barker, R. 1998. World Water Demand and Supply, 1990 to 2025: Scenarios and Issues. Research Report No. 19, International Water Management Institute (IWMI), Colombo, Sri Lanka.

UN. 2002. World Population Prospects. http://esa.un.org/unpp/p2k0data.asp

UNECA (UN Economic Commission for Africa) 2001. World Population Prospects and Population Data Base. http://www.uneca.org/fssdd/programme overview/population/southern africa.htm

Webb, P. and Iskandarani, M. 1998. Water Insecurity and the Poor: Issues and research needs. ZEFDiscussion Papers on Development Policy. Center for Development Research (ZEF), University of Bonn, Bonn.

WHO (World Health Organization) 1998. World Health report: Life in the $21^{\text {st }}$ Century, A Vision for All. WHO, Geneva. 